Article

\title{
Synthesis and Evaluation of Scalable D-A-D $\pi$-Extended Oligomers as p-Type Organic Materials for Bulk-Heterojunction Solar Cells
}

\author{
Peshawa Osw ${ }^{1,2}{ }^{\text {, Andrea Nitti }}{ }^{1}{ }^{\mathbb{D}}$, Media N. Abdullah $^{2}$, Samuel I. Etkind ${ }^{3} \mathbb{D}^{\text {, }}$ \\ Jeremiah Mwaura ${ }^{4}$, Alessandro Galbiati ${ }^{5}$ and Dario Pasini ${ }^{1, * \mathbb{D}}$ \\ 1 Department of Chemistry and INSTM Research Unit, University of Pavia, Via Taramelli 12, 27100 Pavia, \\ Italy; peshawa.osw@gmail.com (P.O.); andrea.nitti01@universitadipavia.it (A.N.) \\ 2 Department of Chemistry, College of Science, Salahaddin University, 44001 Erbil, Kurdistan, Iraq; \\ media.abdullah@su.edu.krd \\ 3 Department of Chemistry, Massachusetts Institute of Technology, Cambridge, MA 02139, USA; \\ sietkind@mit.edu \\ 4 Research Laboratory of Electronics, Massachusetts Institute of Technology, Cambridge, MA 02139, USA; \\ mwaura@mit.edu \\ 5 New Polyurethane Technologies s.r.l., Via Stazione 12, 27030 Villanova D’ardenghi, Pavia, Italy; \\ a.galbiati@nptsrl.com \\ * Correspondence: dario.pasini@unipv.it; Tel.: +39-0382-987-835
}

Received: 4 February 2020; Accepted: 20 March 2020; Published: 24 March 2020

check for updates

\begin{abstract}
The synthesis and characterization of four novel donor-acceptor-donor $\pi$-extended oligomers, incorporating naphtha(1-b)thiophene-4-carboxylate or benzo(b)thieno(3,2-g) benzothiophene-4-carbo xylate 2-octyldodecyl esters as end-capping moieties, and two different conjugated core fragments, is reported. The end-capping moieties are obtained via a cascade sequence of sustainable organic reactions, and then coupled to benzo(c)(1,2,5)thiadiazole and its difluoro derivative as the electron-poor $\pi$-conjugated cores. The optoelectronic properties of the oligomers are reported. The novel compounds revealed good film forming properties, and when tested in bulk-heterojunction organic photovoltaic cell devices in combination with $\mathrm{PC}_{61} \mathrm{BM}$, revealed good fill factors, but low efficiencies, due to their poor absorption profiles.
\end{abstract}

Keywords: Cascade organic reactions; $\pi$-conjugated oligomers; direct arylation; organic electronics; fused aromatic rings; organic photovoltaics; bulk-heterojunction organic solar cells

\section{Introduction}

The discovery of novel $\pi$-conjugated molecules is of the foremost importance for the continuous development of organic semiconductors for applications in solid-state devices [1-9]. Organic photovoltaic cells (OPVs) with bulk-heterojunction (BHJ) architecture have drawn increasing attention in the past two decades, due to their peculiar features, such as solution processability with ink-jet printing, low cost, and light weight $[10,11]$. Outstanding results, including a new record for Photocurrent Efficiency (PCE) at $14 \%$ for a single junction solar cell and $17.3 \%$ for a tandem solar cell, have been recently reported in the field $[12,13]$.

Although conjugated polymers are the current choice in BHJs, due to their good film forming and mechanical properties $[14,15]$, the use of oligomers as alternative donor materials has been developed recently [16-18]. Conjugated oligomers share some of the electronic properties of conjugated polymers while presenting specific advantages, including their well-defined structure, easier purification 
procedures, and lack of defects. The chemical modularity of such oligomeric architecture allows the fine tuning of absorbance, emission, and molecular orbital levels.

For high performance materials, however, lengthy synthetic sequences can be problematic for industrial scalability. Despite their enormous potential, large scale applications of $\pi$-extended organic materials are hampered by the excessive cost of production, which does not yet take into account established sustainability indexes like the $\mathrm{E}$ factor ( $\mathrm{kg}$ of organic waste/ $\mathrm{kg}$ of product) [19]. E factor values for organic semiconductors are often in the excess of $10^{4}$, in some cases largely surpassing those for organic small molecules, which are active components of pharmaceutical formulations [20-22]. Our group has recently introduced a one-pot cascade methodology, comprising direct arylation (DHA) [23-27] and cross aldol condensations as the sequence of two alkaline-mediated reactions in a single process. The DHA step, occurring regio-specifically on the 2-position of 3-thiopheneacetic acid, facilitates the subsequent cross aldol step, which completes the formation of an annulated aromatic ring. Our methodology is a sustainable tool for the annulation [28-30] of $\pi$-extended thiophene-based systems (Figure 1, top left) [31,32].

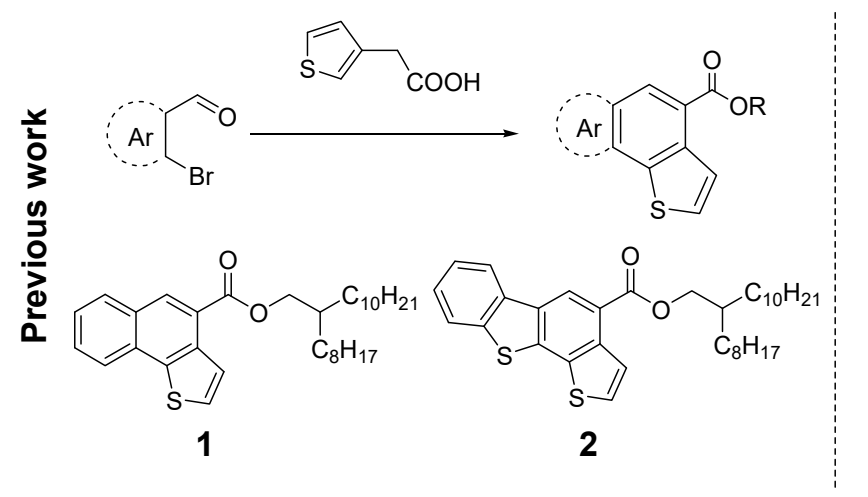

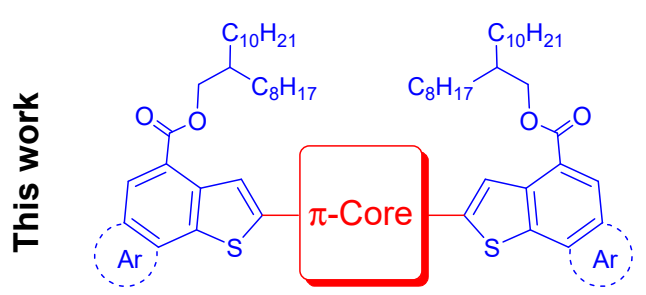

$D-A-D \pi$-Oligomers

Figure 1. Left: reaction scheme for direct arylation (DHA)-cross aldol condensation between $o$-bromoaldehydes and 3-thiopheneacetic acid for the synthesis of annulated scaffolds $\mathbf{1}$ and $\mathbf{2}$. Right: general depiction of novel oligomers synthesized and discussed in this work.

We set out to investigate the possibility of using such easily obtainable $\pi$-systems in larger $\pi$-systems, with suitable optical and electronic characteristics to function as donors in OPV $\mathrm{BHJ}$ cells. We previously reported one-step syntheses of naphtha(1-b)thiophene-4-carboxylate or benzo(b)thieno(3,2-g)benzothiophene-4-carboxylate 2-octyldodecyl esters 1 and 2, respectively [33]. Naphthothiophene and benzodithiophene derivatives $\mathbf{1}$ and 2, due to their high planarity and $\pi$-conjugation, appeared as suitable end-capping units for the rapid construction of oligomers incorporating electron-withdrawing units as the central cores, thus forming donor-acceptor-donor (D-A-D) architectures with tunable energy levels for OPV applications (Figure 1). Benzo(c)(1,2,5)thiadiazole (BT) has considerable utility in organic photovoltaics, solar concentrators, OLED, and OFET [34-36]. In this paper we present the synthesis of novel D-A-D oligomers with BT and its difluoro derivative as the electron-poor $\pi$-conjugated cores, and we present data on their performance as p-type donor components of bulk-heterojunction (BHJ) organic solar cells.

\section{Results and Discussion}

\subsection{Design, Synthesis, NMR, and Photophysical Characterization}

Compounds $\mathbf{1}$ and $\mathbf{2}$ represented a good starting point for us, as we have demonstrated the ability to selectively functionalize the $\alpha$-position of terminal thiophene units, introducing reactive functional groups such as bromine or tin derivatives for further extension of the $\pi$-scaffold. BT units were our choice as the electron-withdrawing $\pi$-cores, in order to form donor-acceptor-donor oligomers with suitable energy levels to work efficiently as p-type materials in $\mathrm{BHJ}$ cells. Thiophene rings on both 
sides of the BT units were designed to enhance conjugation and shift HOMO-LUMO levels to optimal values for BHJ applications.

The synthesis of the oligomers is shown in Scheme 1. The syntheses afforded linear products in high yields, starting from elaborated end-capping of conjugated units, obtained through sustainable annulation reaction methodologies, and decorated with $\mathrm{C}_{20}$ branched alkyl chains to improve solubility. Functionalized BT units $\mathbf{5}$ and $\mathbf{6}$ were prepared through procedures found in the literature. We initially attempted a DHA protocol for the synthesis of oligomers 7-10, by using 5 or $\mathbf{6}$ as substrates in combination with $\mathbf{1}$ and 2, but we did not observe, in each case, the formation of the desired products 7-10 if not in trace amounts. To overcome the synthetic difficulties observed using the DHA protocol, we evaluated the synthesis of compounds 7-10 using a Stille protocol. Compounds 3 and $\mathbf{4}$ were obtained in good yields by stannylation of compounds $\mathbf{1}$ and $\mathbf{2}$ performed using lithium diisopropylamde (LDA) as a lithiating agent and tributyltin chloride, as previously reported. [33] Compounds 7-10 were thus obtained by Stille reactions in high yields after careful purification by column chromatography. The structures of the pure compounds were confirmed using $1 \mathrm{D}$ and 2D NMR spectroscopy, and high resolution MALDI-TOF (see Supporting Information).

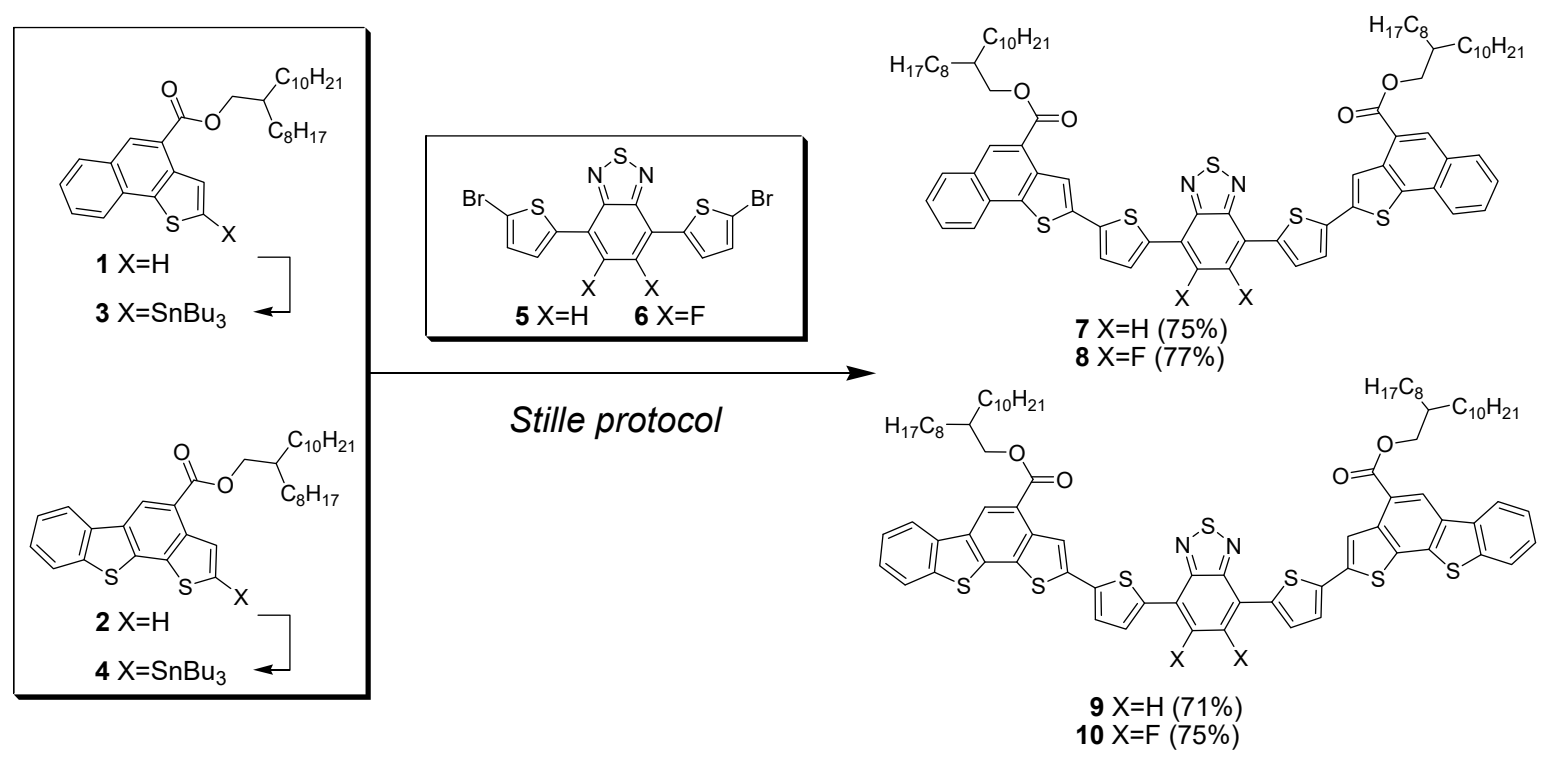

Scheme 1. Synthesis of donor-BT-donor oligomers 7-10. Reaction conditions for the Stille protocol: $\mathrm{Pd}\left(\mathrm{PPh}_{3}\right)_{4}$, dry Toluene, reflux, $24 \mathrm{~h}$.

An inspection and comparison of the ${ }^{1} \mathrm{H}$ NMR spectra (Figure 2) for compounds 7-10 revealed marked differences between them. All compounds show broadening of virtually all proton resonances, demonstrating that although the compounds remained fully soluble in the NMR test tube, they tend to aggregate in the non-polar solvent used for the NMR spectra $\left(\mathrm{CDCl}_{3}\right)$. The difference in cross-talking between the $\pi$-electron rich end-capping units and the central $\pi$-electron deficient core appears evident, particularly in comparing the fluorinated vs. non fluorinated residues (see 7 vs. 8 and 9 vs. 10), and demonstrated by the large shift of several proton resonances (identified with colored dots in Figure 2).

The absorption and emission spectra for all oligomers are shown in Figure 3, and the photophysical properties of $\mathbf{7 - 1 0}$ in $\mathrm{CHCl}_{3}$ are summarized in Table 1 . The UV-Vis spectra of all compounds show a low energy band between 500 and $515 \mathrm{~nm}$, likely arising from $\pi-\pi^{*}$ transitions. Compounds 7-10 show very similar optical $\pi-\pi^{*}$ transition energies, calculated through the Tauc plot method from their UV-Vis spectra. Comparing UV-Vis spectra of $\mathbf{7}$ with 8 and $\mathbf{9}$ with 10, significant red shifts of 10-15 nm were observed upon fluorination. The bathochromic shifts by the introduction of fluorine in the BT backbone are in agreement with previous observations [37]. High molar absorption coefficients and 
low band gaps are beneficial to enhancing short circuit current density $\left(\mathrm{J}_{S C}\right)$ in OPVs. Oligomers 7-10 exhibited adequate band gaps, but rather small absorption coefficients (ca. one order of magnitude lower than high-performing literature examples) [16]. All oligomers exhibit essentially superimposable emission spectra, with intense emission bands centered between 610 and $630 \mathrm{~nm}$, and broad profiles, typical of conjugated oligomers with substantial degrees of conformational freedom. Fluorescence lifetimes were as expected in the nanosecond range.

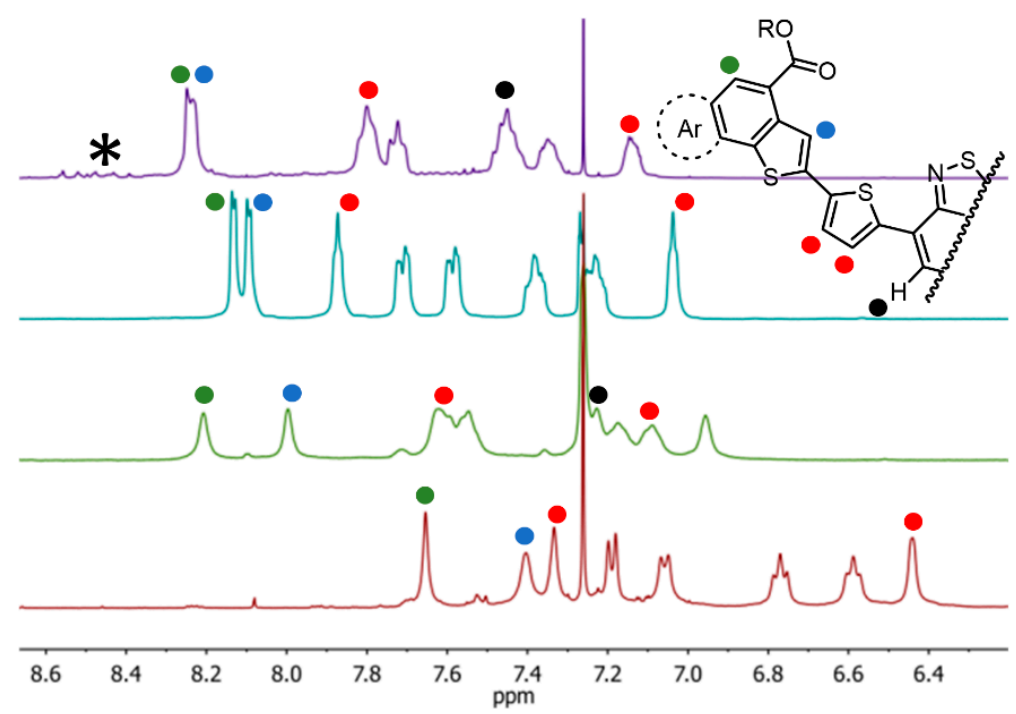

Figure 2. Stacked ${ }^{1} \mathrm{H}$ NMR (200 MHz, $\mathrm{CDCl}_{3}$ ) of compounds (from top to bottom): 7 (pink), 8 (blue), 9 (green) and 10 (red). The asterisk denotes small impurities present in the sample of compound 7.
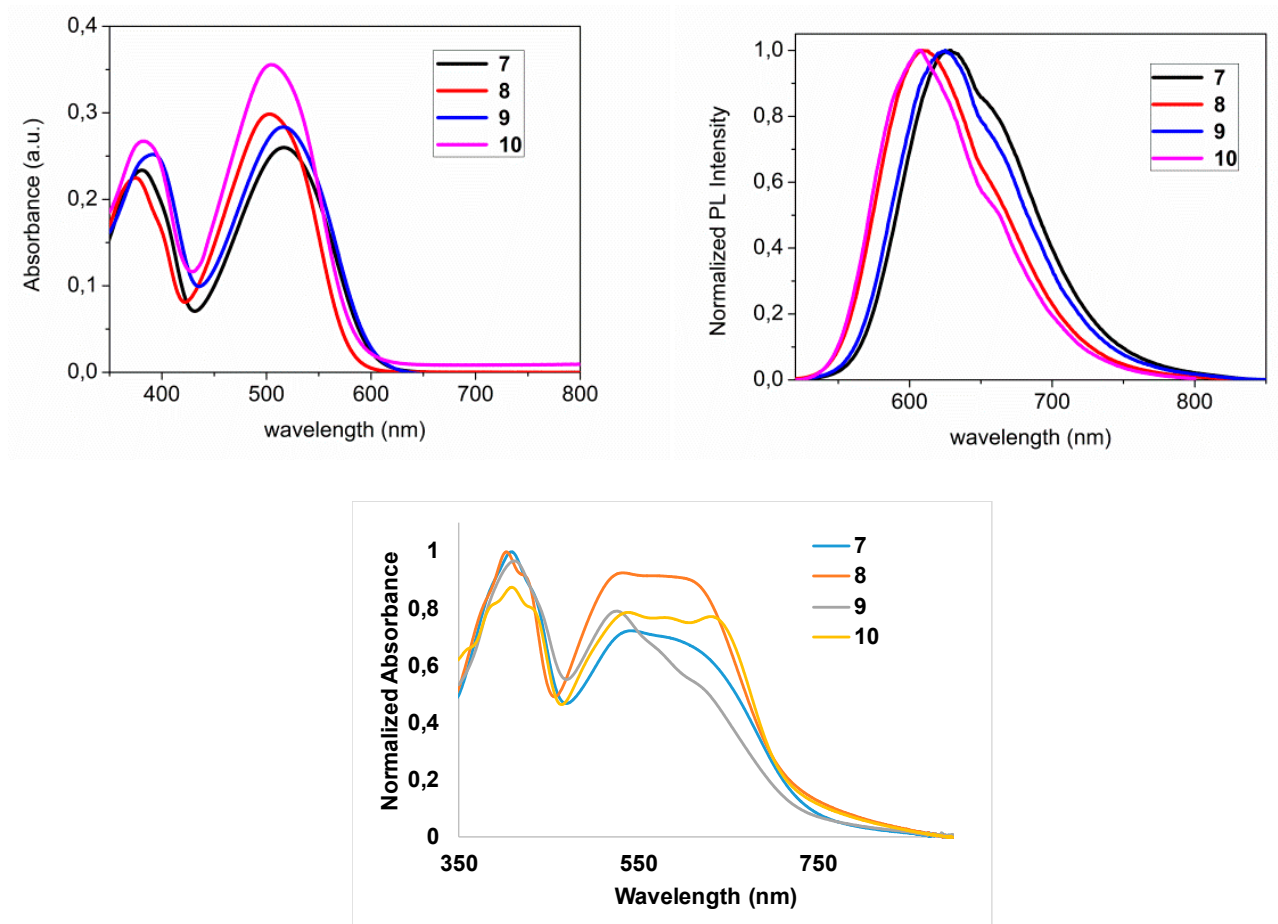

Figure 3. Absorption spectra (left), photoluminescence (PL) spectra (right) and solid state absorption spectra (bottom) of compounds 7 (black), 8 (red), 9 (blue), and 10 (violet) in DCM $\left(10^{-5}-10^{-6} \mathrm{M}\right.$ ). 
Table 1. Photophysical properties in solution and in the solid state for oligomers 7-10. ${ }^{1}$

\begin{tabular}{|c|c|c|c|c|c|c|}
\hline Compound & $\max a b s(n m)$ & $\left(\mathrm{cm}^{-1} \cdot \mathrm{mol}^{-1} \cdot \mathrm{L}\right)$ & $\mathrm{E}_{g}{ }^{o p t}(\mathrm{eV})$ & em $(n m)$ & (ns) & $\max a b s(n m)^{2}$ \\
\hline 7 & 516 & $1.31 \cdot 104$ & 2.06 & 627 & 4.2 & 610 (broad) \\
\hline 8 & 502 & $1.61 \cdot 104$ & 2.13 & 610 & 3.3 & 615 (broad) \\
\hline 9 & 515 & $1.40 \cdot 104$ & 2.05 & 622 & 3.4 & 618 (broad) \\
\hline 10 & 505 & $1.66 \cdot 104$ & 2.11 & 607 & 2.5 & 628 \\
\hline
\end{tabular}

${ }^{1}$ Experiments carried out in dichloromethane $(\mathrm{DCM})$ solutions $\left(1 \times 10^{-5}-3 \times 10^{-5} \mathrm{M}\right)$ in the absorption mode, and DCM solutions $\left(1 \times 10^{-6}-3 \times 10^{-6} \mathrm{M}\right)$ in the emission mode. ${ }^{2}$ Solid state films fabricated by spin coating of the compound from $\mathrm{CHCl}_{3}$ solution.

The electrochemical properties of oligomers $\mathbf{7 - 1 0}$ were investigated by cyclic voltammetry (CV) in $\mathrm{CH}_{2} \mathrm{Cl}_{2}$ solutions and at $0.2-1.0 \mathrm{mM}$ concentrations on a glassy carbon working electrode in $0.1 \mathrm{M}$ $\left[\mathrm{nBu}_{4} \mathrm{~N}^{+}\left[\mathrm{PF}_{6}\right]^{-}\right.$(see Supporting Information for $\mathrm{CV}$ curves). $\mathrm{CV}$ could not be run for oligomer 10 due to its poor solubility in $\mathrm{CH}_{2} \mathrm{Cl}_{2}$ and other suitable solvents for $\mathrm{CV}$. All oligomers showed irreversible reduction and oxidation waves. The HOMO and LUMO energies were estimated from the onset oxidation and reduction potentials, respectively, assuming the absolute energy level of $\mathrm{FeCp}_{2}{ }^{+/ 0}$ to be $4.8 \mathrm{eV}$ below vacuum. [38] The HOMO-LUMO electrochemical gaps are represented graphically in Figure 4 (right). For oligomers 7-9 the HOMO-LUMO gaps estimated by CV are smaller than the optical band gaps, as observed for other types of molecules and polymers in the literature [16]. The electrochemical band gaps for oligomers 7-9 are in line with those of oligomers showing high photocurrent efficiencies (PCE) in BHJ OPV devices, and thus deemed to be applicable for studies in combination with $\mathrm{PC}_{61} \mathrm{BM}$ [16]. For example, the LUMO level of 9 is $0.5 \mathrm{eV}$ higher than that $(-3.9 \mathrm{eV})$ of $\mathrm{PC}_{61} \mathrm{BM}$ [39], and the LUMO gap between the donor oligomer 9 and the acceptor $\mathrm{PC}_{61} \mathrm{BM}$ is large enough to guarantee photoinduced electron transfer between them $[40,41]$. The difference between the $\mathrm{HOMO}$ of 9 and the LUMO of $\mathrm{PC}_{61} \mathrm{BM}$ is $1.3 \mathrm{eV}$, which could lead to high open-circuit voltage $\left(\mathrm{V}_{\mathrm{OC}}\right)$ in solar cells [42].

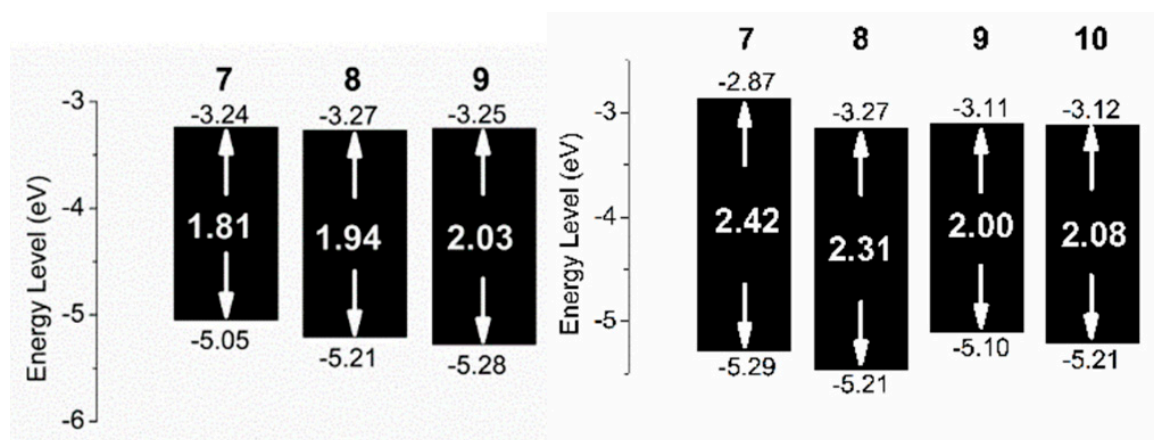

Figure 4. HOMO-LUMO energy levels for oligomers 7-9 as calculated by cyclic voltammetry (CV) in solution (left) and in the solid state (right).

The CV measurements were also determined in the solid state and the derived HOMO-LUMO electrochemical gaps are represented graphically in Figure 4 (left). For oligomers 7-9, we see a reverse trend in the HOMO-LUMO gaps with the solution phase measurement, with the smaller molecules giving a larger band gap. The trend could be attributed to stabilization of charge, which large molecules are better at, and the low local concentration of supporting electrolytes relative to the solution phase measurements. The second scan from CV was used (see Supporting Information for CV curves), and further scans were essentially superimposable.

A comparison between our D-A-D systems incorporating new donors could be carried out using literature data on those systems incorporating BT as the core. Several of such systems are known, for example, in D-A-D analogs of $\mathbf{7}$ and $\mathbf{9}$, incorporating BT and a very strong donor such as ethylenedioxythiophene, and the HOMO-LUMO energy level determined by CV in solution resulted to be -5.02 and $-3.42 \mathrm{eV}$, values which differ considerably from those of $\mathbf{7}$ and $\mathbf{9}$. Such values 
substantiate the difference in structures and electron-donating abilities between our new donors and established molecular fragments with strong electron-donating characters. To understand the role of the HOMO-LUMO structures with respect to the intended donor-BT-donor structure, density functional theory (DFT) calculations were undertaken using the $\omega$ B97X-D functional with the $6-31 G^{*}$ basis set. The orbital structures of molecules 7-10 are shown in the Supporting Information. As expected, the HOMO is delocalized primarily over the donor unit, while the LUMO resides primarily on the BT unit.

\subsection{BHJ OPV Devices}

In order to verify potential applications of the new oligomers in BHJ OPVs, we used 7, 9, and 10 as an electron donor and $\mathrm{PC}_{61} \mathrm{BM}$ as an electron acceptor in a 1:1 ratio (w:w). Oligomer 8 was not investigated further because of the poor solubility in the solvent mixture used for the spin coating (8:2 chlorobenzene/chloroform). The BHJ OPVs devices were fabricated with a structure of glass/ITO/ZnO/active layer/ $\mathrm{MoO}_{3} / \mathrm{Ag}$. Table 2 summarizes the $\mathrm{V}_{\mathrm{OC}}$, JSC, fill factor (FF), and PCE of the devices. The active layer components formed homogeneous, good quality films by spin coating, and film thicknesses could be easily controlled and optimized to 70-100 nm. The devices showed respectable values for $\mathrm{V}_{\mathrm{OC}}$ and $\mathrm{FF}$, but $\mathrm{J}_{\mathrm{SC}}$ values were at least one order of magnitude lower than high performing oligomers reported in the literature. For example, in a representative, efficient $\mathrm{BHJ}$ cell built using an oligomer conjugated compound in combination with $\mathrm{PC}_{61} \mathrm{BM}$, the $\mathrm{V}_{\mathrm{OC}}$, $\mathrm{J}_{\mathrm{SC}}$, and $\mathrm{FF}$ values were, respectively, $0.88 \mathrm{~V}, 6.30 \mathrm{~mA} / \mathrm{cm}^{2}$, and 0.75 [16]. The PCE values obtained on our systems were therefore rather disappointing, and optimization was not preformed further.

Table 2. The device data of organic photovoltaic cells (OPVs) based on 7-10:PC 61 BM 1:1 under the illumination of a $150 \mathrm{~W}$ full spectrum solar simulator. ${ }^{1}$

\begin{tabular}{ccccc}
\hline Compound & Voc $(\mathbf{V})$ & Jsc $\left(\mathbf{m A} / \mathbf{c m}^{\mathbf{2}}\right)$ & FF & PCE (\%) \\
\hline $\mathbf{7}$ & 0.74 & 0.55 & 0.34 & 0.14 \\
$\mathbf{9}$ & 0.81 & 0.89 & 0.52 & 0.37 \\
$\mathbf{1 0}$ & 0.51 & 0.78 & 0.44 & 0.17 \\
\hline
\end{tabular}

1 Films thicknesses between 70 and $100 \mathrm{~nm}$, from 1:1 (w/w) mixtures of oligomer:PC ${ }_{61} \mathrm{BM}$ in $8: 2$ chlorobenzene/chloroform. Oligomer $\mathbf{8}$ was insoluble in the solvent mixture used.

\section{Materials and Methods}

\subsection{General Experimental}

All commercially available reagents and solvents were purchased from Sigma-Aldrich, Fluorochem, Alfa Aesar, and TCI. They were all used as received unless otherwise specified. Compounds 1 [33], 3 [33], 5 [43], and 6 [43] were prepared as previously described. THF (Na) and $\mathrm{CH}_{2} \mathrm{Cl}_{2}\left(\mathrm{CaH}_{2}\right)$ were dried before use. Analytical thin layer chromatography was performed on silica gel, chromophore-loaded, commercially available plates. Flash chromatography was carried out using Merck silica gel 60 (pore size $60 \AA$, 270-400 Mesh). ${ }^{1} \mathrm{H}$ and ${ }^{13} \mathrm{C}$ NMR spectra were recorded from solutions in deuterated solvents on 300 Bruker spectrometers or $400 \mathrm{Jeol}$, with the solvent residual proton signal or tetramethylsilane as a standard. Low resolution mass spectra of pure compounds were recorded using an Agilent Technologies ESI-MS spectrometer, and high resolution mass spectra were recorded using a Bruker Autoflex MALDI-TOF in reflectron mode with trans-2-(3-(4-tert-Butylphenyl)-2-methyl-2-propenylidene) malononitrile (DCTB) as a matrix. The UV-Vis spectroscopic studies were recorded using a JASCO V-550 spectrophotometer. The PL and PLE spectra were recorded using a Perkin Elmer LS55 luminescence spectrophotometer and Horiba fluorolog for lifetime measurements. Solid state UV-Vis measurements were performed on glass slides, which were cleaned by sonication first in acetone, then $\mathrm{EtOH}$, and then water, followed by an ozone clean. The compounds were deposited by spin coating a filtered $10 \mathrm{mg} / \mathrm{mL}$ solution of the compound in $\mathrm{CHCl}_{3}$ at $1500 \mathrm{rpm}$ for $30 \mathrm{~s}$. Due to the softness of the films, assessment of 
the film thickness by profilometry was not possible. Cyclic voltammetry experiments were carried out using a Biologic SP-150 potentiostat with a polished glassy carbon working electrode, platinum counter electrode, silver pseudo-reference electrode, and tetrabutylammonium hexofluorophosphate (recrystallized three times from EtOH) as a supporting electrolyte. Sample concentrations were between 0.2 and $1.0 \mathrm{mM}$. All electrochemical measurements were referenced to the $\mathrm{Fc} / \mathrm{Fc}^{+}$redox couple. Band gaps were estimated using the onset of the initial oxidation and reduction events, and $\mathrm{E}_{\mathrm{HOMO}}$ and $\mathrm{E}_{\mathrm{LUMO}}$ were estimated given an $\mathrm{E}_{\mathrm{HOMO}}$ of $4.80 \mathrm{eV}$ for ferrocene. Samples for solid state $\mathrm{CV}$ measurements were prepared by drop-casting $15 \mu \mathrm{L}$ of a solution of the compound in $\mathrm{CHCl}_{3}$ $(\sim 1 \mathrm{mg} / \mathrm{mL})$ onto a glassy carbon electrode and allowed to dry at room temperature. The electrode was then submerged in a solution of $0.1 \mathrm{M}$ tetrabutylammonium hexafluorophosphate $\left(\mathrm{TBAPF}_{6}\right)$ in $\mathrm{MeCN}$, and measurements were taken at $100 \mathrm{mV} / \mathrm{s}$. In all figures (see Supporting Information section), the second scan is shown, which is similar to subsequent scans. Theoretical calculations were carried out with the Spartan '18 (1.4.4, Wave function Inc, Irvine CA) software packages on a computer operating with Windows 10 OS. Geometry optimizations and energy calculations was performed with density functional theory (DFT) calculations using the $\omega$ B97X-D functional with the 6-31G* basis set in the gas phase. Solubilizing alkyl groups were replaced with methyl groups for simplicity.

\subsection{General Procedure for the Stille Protocol for the Synthesis of the Small Oligomers}

Selected Example for the Synthesis of Compound 7

A two-neck flask flame-dried and equipped with a condenser was charged under argon atmosphere with compound 3 ( $319 \mathrm{mg}, 0.4 \mathrm{mmol}, 2 \mathrm{eq})$, 4,7-bis(5-bromothiophen-2-yl) benzo (c) (1,2,5)thiadiazole $5(91.6 \mathrm{mg}, 0.2 \mathrm{mmol}, 1 \mathrm{eq})$ and dry toluene $\left(2 \mathrm{~mL}, 0.1 \mathrm{~mol} \cdot \mathrm{L}^{-1}\right)$. The solution was degassed for 5 min and $\mathrm{Pd}\left(\mathrm{PPh}_{3}\right)_{4}(4.62 \mathrm{mg}, 4 \mu \mathrm{mol}, 0.02 \mathrm{eq})$ was added in one portion, then degassed for $10 \mathrm{~min}$. The reaction mixture was warmed to $100^{\circ} \mathrm{C}$ and kept under stirring at the same temperature for $24 \mathrm{~h}$. After TLC monitoring (eluent 7:3 petroleum ether:DCM, $R_{\mathrm{f}}=0.41$ ), the reaction solvent was removed under reduced pressure and the crude reaction mixture was purified by flash chromatography $\left(\mathrm{SiO}_{2}\right.$; petroleum ether:DCM 8:2). The pure product was obtained as a dark red solid (149 mg, 75\%).

bis(2-octyldodecyl) 2,2'-(5,5'-(benzo(c)(1,2,5)thiadiazole-4,7-diyl)bis(thiophene-5,2-diyl))bis(naphtha (1-b)thiophene-4-carboxylate) (7). Dark red solid (149 mg, 75\% yield). ${ }^{1} \mathrm{H}$ NMR (400 MHz, $\left.\mathrm{CDCl}_{3}\right) \delta$ : 8.27-8.20 (m, 4H), 7.84-7.76 (m, 4H), $7.73(\mathrm{~d}, J=7.5 \mathrm{~Hz}, 2 \mathrm{H}), 7.50-7.41(\mathrm{~m}, 4 \mathrm{H}), 7.35(\mathrm{~s}, 2 \mathrm{H}), 7.18-7.10$ $(\mathrm{m}, 2 \mathrm{H}), 4.46-4.28(\mathrm{~m}, 4 \mathrm{H}), 2.01-1.84(\mathrm{~m}, 2 \mathrm{H}), 1.62-1.17(\mathrm{~m}, 65 \mathrm{H}), 0.87(\mathrm{t}, J=7.7 \mathrm{~Hz}, 12 \mathrm{H}) .{ }^{13} \mathrm{C} \mathrm{NMR}$ $\left(101 \mathrm{MHz}, \mathrm{CDCl}_{3}\right) \delta: 166.96,152.32,139.47,138.33,137.43,136.28,130.95,130.67,130.54,129.78,129.30$, $129.17,128.36,126.26,125.81,125.32,124.91,123.70,123.38,122.24,68.49,66.23,41.01,38.07,32.41,32.12$, 31.40, 30.60, 30.20, 29.87, 23.17, 14.60. HRMS (MALDI-TOF): Calcd: 1312.6287. Found: 1312.6315.

bis(2-octyldodecyl) 2,2'-(5,5'-(5,6-difluorobenzo(c)(1,2,5)thiadiazole-4,7-diyl)bis(thiophene-5,2-diyl))bis(naphtha(1-b)thiophene-4-carboxylate) (8). Dark Red solid (207 mg, 77\% yield). ${ }^{1} \mathrm{H}$ NMR (400 MHz, $\left.\mathrm{CDCl}_{3}\right) \delta: 8.15-8.02(\mathrm{~m}, 4 \mathrm{H}), 7.85(\mathrm{~s}, 2 \mathrm{H}), 7.69(\mathrm{~d}, J=7.8 \mathrm{~Hz}, 2 \mathrm{H}), 7.57(\mathrm{~d}, J=7.8 \mathrm{~Hz}, 2 \mathrm{H}), 7.40-7.32(\mathrm{~m}$, 2H), 7.28-7.15 (m, 2H), $7.02(\mathrm{~s}, 2 \mathrm{H}), 4.42-4.29(\mathrm{~m}, 4 \mathrm{H}), 1.97-1.83(\mathrm{~m}, 2 \mathrm{H}), 1.61-1.13(\mathrm{~m}, 70 \mathrm{H}), 0.93-0.74$ $(\mathrm{m}, 12 \mathrm{H}) .{ }^{19} \mathrm{~F}$ NMR $\left(376 \mathrm{MHz}, \mathrm{CDCl}_{3}\right) \delta:-127.06 .{ }^{13} \mathrm{C} \mathrm{NMR}\left(101 \mathrm{MHz}, \mathrm{CDCl}_{3}\right) \delta: 166.45,147.92,140.54$, $138.02,136.58,135.73,130.48,130.12,130.03,129.30,128.68,125.84,124.61,123.21,122.85,121.95,115.34$, 113.96, 113.60, 110.55, 37.65, 32.05, 31.74, 30.22, 29.83, 29.50, 27.04, 22.81, 14.23. HRMS (MALDI-TOF): Calcd: 1348.6098. Found: 1348.6090.

bis(2-octyldodecyl) 2,2'-(5,5'-(benzo(c)(1,2,5)thiadiazole-4,7-diyl)bis(thiophene-5,2-diyl))bis(benzo-(b)thieno (3,2-g)benzothiophene-4-carboxylate) (9). Dark red solid (202 mg, 71\% yield). ${ }^{1} \mathrm{H} \mathrm{NMR}\left(400 \mathrm{MHz}, \mathrm{CDCl}_{3}\right)$ $\delta: ~ 8.28-8.12(\mathrm{~m}, 2 \mathrm{H}), 8.04-7.92(\mathrm{~m}, 2 \mathrm{H}), 7.69-7.47(\mathrm{~m}, 6 \mathrm{H}), 7.25-7.03(\mathrm{~m}, 6 \mathrm{H}), 7.00-6.87(\mathrm{~m}, 2 \mathrm{H})$, $4.50-4.35(\mathrm{~m}, 4 \mathrm{H}), 2.08-1.86(\mathrm{~m}, 2 \mathrm{H}), 1.62-1.03(\mathrm{~m}, 70 \mathrm{H}), 0.89(\mathrm{~s}, 12 \mathrm{H}) .{ }^{13} \mathrm{C} \mathrm{NMR}\left(101 \mathrm{MHz}, \mathrm{CDCl}_{3}\right) \delta$ : $166.45,147.92,140.54,138.02,136.58,135.73,131.66,131.35,130.48,130.12,130.03,129.30,128.68,125.84$, $124.61,123.21,122.85,121.95,115.34,113.96,113.60,110.55,37.65,32.05,31.74,30.22,29.83,29.50,27.04$, 22.81, 14.23. HRMS (MALDI-TOF): Calcd: 1424.5728. Found: 1424.5802. 
bis(2-octyldodecyl) 2,2'-(5,5'-(5,6-difluorobenzo(c)(1,2,5)thiadiazole-4,7-diyl)bis(thiophene-5,2-diyl))bis(benzo(b)thieno(3,2-g)benzothiophene-4-carboxylate) (10). Dark red solid (219 mg, 75\% yield). ${ }^{1} \mathrm{H}$ NMR $\left(400 \mathrm{MHz}, \mathrm{CDCl}_{3}\right) \delta: 7.65(\mathrm{~s}, 2 \mathrm{H}), 7.40(\mathrm{~s}, 2 \mathrm{H}), 7.33(\mathrm{~s}, 2 \mathrm{H}), 7.19(\mathrm{~d}, J=7.2 \mathrm{~Hz}, 2 \mathrm{H}), 7.06(\mathrm{~d}, J=7.2$ $\mathrm{Hz}, 2 \mathrm{H}), 6.77(\mathrm{t}, J=6.6 \mathrm{~Hz}, 2 \mathrm{H}), 6.59(\mathrm{t}, J=6.1 \mathrm{~Hz}, 2 \mathrm{H}), 6.44(\mathrm{~s}, 2 \mathrm{H}), 4.34-4.22(\mathrm{~m}, 4 \mathrm{H}), 1.93-1.75$ $(\mathrm{m}, 2 \mathrm{H}), 1.63-1.17(\mathrm{~m}, 70 \mathrm{H}), 0.98-0.84(\mathrm{~m}, 12 \mathrm{H}) .{ }^{19} \mathrm{~F} \mathrm{NMR}\left(376 \mathrm{MHz}, \mathrm{CDCl}_{3}\right) \delta:-126.99 .{ }^{13} \mathrm{C} \mathrm{NMR}$ $\left(101 \mathrm{MHz}, \mathrm{CDCl}_{3}\right) \delta: 166.13,147.26,137.96,137.30,136.85,136.42,136.06,134.97,132.71,131.60,130.63$, 130.56, 128.94, 128.52, 128.11, 125.79, 124.49, 124.20, 124.08, 123.05, 121.94, 120.75, 118.52, 67.72, 40.39, $40.17,39.97,37.65,32.19,32.14,31.83,30.37,30.02,29.95,29.81,29.61,27.14,22.88,14.34,14.31$. HRMS (MALDI-TOF): Calcd: 1460.5540 . Found: 1460.5556.

\subsection{Fabrication and Characterization of Photovoltaic Cells}

Photovoltaic cells were fabricated with an inverted structure geometry (glass/ITO/ZnO/active layer $/ \mathrm{MoO}_{3} / \mathrm{Ag}$ ). $\quad \mathrm{PC}_{61} \mathrm{BM}$ was purchased from Aldrich and used without further purification. Patterned indium tin oxide (ITO)-coated glass substrates ( 20 ohm/sq), purchased from Thin Film Devices, were sonicated in acetone $(10 \mathrm{~min})$ and isopropyl alcohol $(10 \mathrm{~min})$ and UV-Ozone cleaned (10 $\mathrm{min}$ ) immediately prior to deposition of the device layers. $\mathrm{ZnO}$ nanoparticles $(2.5 \% \mathrm{w} / \mathrm{w}$ solution in isopropanol) purchased from Aldrich, were spin-coated in ambient conditions at $3000 \mathrm{rpm}$ and annealed for $5 \mathrm{~min}$ at $120^{\circ} \mathrm{C}$. A $40 \mathrm{~nm}$ thick electron transport layer (ETL) was thus obtained. For the active layer, a $20 \mathrm{mg} / \mathrm{mL}$ solution of 1:1 total Oligomer/ $\mathrm{PC}_{61} \mathrm{BM}$ in 8:2 chlorobenzene:chloroform was employed. The active layer solution was stirred for $3 \mathrm{~h}$ at $65^{\circ} \mathrm{C}$ before use. A $50 \mu \mathrm{L}$ aliquot of this solution was then spin-coated onto the $\mathrm{ZnO}$ layer at $1000 \mathrm{rpm}$ in ambient conditions and annealed for 3 min at $120^{\circ} \mathrm{C}$ on a hot plate, resulting in 70-100 nm thick films. Following this spin-coating deposition procedure, a $10 \mathrm{~nm}$ thick layer of molybdenum trioxide $\left(\mathrm{MoO}_{3}\right)$ hole transport layer $(\mathrm{HTL})$ and a silver back contact electrode (100 $\mathrm{nm}$ thick) were sequentially deposited by vacuum evaporation through a shadow mask at $10^{-6}$ torr. Each device had an area of $5 \mathrm{~mm}^{2}$, with 6 devices per substrate. The J-V curves were measured and calculated using a solar simulator in air (Newport Oriel Class A, Sol3A) connected to a source meter (Keithley 2631-A) under 1 sun illumination with intensity of $1000 \mathrm{~W} / \mathrm{m}^{2}$ (AM 1.5 G).

\section{Conclusions}

We have reported the design, synthesis, and characterization of four novel $\pi$-extended conjugated oligomers with a D-A-D (donor-acceptor-donor) overall structure, and we have tested them as the donor components for OPV BHJ cells. The central cores were $\pi$-electron deficient BT-based residues that were extended with thiophene units on both sides to maximize conjugation and cross-talking between the $\pi$-electron rich and deficient parts of the oligomeric units. Determination of the HOMO and LUMO levels, when compared with D-A-D oligomers known in the literature, demonstrated a different and "milder" donor character of our donor units when compared with other, robust donors (e.g., ehtylenedioxythiophene). NMR spectroscopy showed broadening of the peaks, demonstrating the tendency of such molecules to form discrete stacks through noncovalent interactions, while maintaining full solubility in non-polar solvents. The optically- and electrochemically-determined band gaps were consistent with applications in BHJ OPV architectures, but their molar absorptivity coefficients were too low in the visible region for high PCEs [16]. The consequence is that the JSC values were at least one order of magnitude lower than the state-of-the-art devices described in the literature, bringing the overall efficiencies to modest levels. Although not optimized further for BHJ, in view of their straightforward synthesis and modular construction, we believe the design of such oligomers will stimulate further activity for the elaboration of structurally-related conjugated moieties with improved performances in BHJ OPV cells, or in other applications involving organic semiconductors. Our design rules for the synthesis of the conjugated monomers/oligomers, heavily based on the sustainability and scalability of chemical synthesis, will become increasingly important once the optoelectronic characteristics of our systems matches what is currently state-of-the-art in terms of performance. 
Current trends in the design of state-of-the art-devices are guiding our efforts in improving our molecular systems [44-48].

Supplementary Materials: The following are available online at http://www.mdpi.com/2073-4360/12/3/720/s1, copies of NMR and CV spectra for new oligomers, and J-V curves for devices.

Author Contributions: Conceptualization, D.P., A.N., M.N.A. and P.O.; Methodology, A.N., S.I.E., J.M., A.G. and P.O.; Writing — original draft preparation, D.P., S.I.E., A.N. and P.O.; Writing-review and editing, D.P.; Supervision, D.P. All authors have read and agreed to the published version of the manuscript.

Funding: This research was supported by MIUR (PRIN 2017 BOOSTER Prot. 2017YXX8AZ) and the University of Pavia (postdoctoral fellowship to A.N., funding to D.P. for visiting professorship at MIT Progetto Pavia- Boston 2019). The authors acknowledge financial support from the European Commission under the Horizon 2020 Programme by means of the grant agreement No. 731019 EUSMI.

Acknowledgments: The authors acknowledge Tim Swager (MIT) for useful discussion.

Conflicts of Interest: The authors declare no conflict of interest.

\section{References}

1. Li, H.; Shi, W.; Song, J.; Jang, H.-J.; Dailey, J.; Yu, J.; Katz, H.E. Chemical and Biomolecule Sensing with Organic Field-Effect Transistors. Chem. Rev. 2019, 119, 3-35. [CrossRef]

2. Torsi, L.; Magliulo, M.; Manolia, K.; Palazzo, G. Organic field-effect transistor sensors: a tutorial review. Chem. Soc. Rev. 2013, 42, 8612-8628. [CrossRef] [PubMed]

3. Usta, H.; Facchetti, A.; Marks, T.J. n-Channel Semiconductor Materials Design for Organic Complementary Circuits. Acc. Chem. Res. 2011, 44, 501-510. [CrossRef] [PubMed]

4. Chatterjee, T.; Wong, K.T. Perspective on Host Materials for Thermally Activated Delayed Fluorescence Organic Light Emitting Diodes. Adv. Opt. Mater. 2019, 7, 1800565. [CrossRef]

5. Yang, Z.Y.; Mao, Z.; Xie, Z.L.; Zhang, Y.; Liu, S.W.; Zhao, J.; Xu, J.; Chi, Z.; Aldred, M.P. Recent advances in organic thermally activated delayed fluorescence materials. Chem. Soc. Rev. 2017, 46, 915-1016. [CrossRef]

6. Ahmadi, M.; Wu, T.; Hu, B. A Review on Organic-Inorganic Halide Perovskite Photodetectors: Device Engineering and Fundamental Physics. Adv. Mater. 2017, 29, 1605242. [CrossRef]

7. Heeger, A.J. 25th anniversary article: Bulk heterojunction solar cells: understanding the mechanism of operation. Adv. Mater. 2014, 26, 10-28. [CrossRef]

8. McQuade, D.T.; Pullen, A.E.; Swager, T.M. Conjugated polymer-based chemical sensors. Chem. Rev. 2000, 100, 2537-2574. [CrossRef]

9. Beaujuge, P.M.; Reynolds, J.R. Color control in $\pi$-conjugated organic polymers for use in electrochromic devices. Chem. Rev. 2010, 110, 268-320. [CrossRef]

10. Zhang, G.; Zhao, J.; Chow, P.C.Y.; Jiang, K.; Zhang, J.; Zhu, Z.; Zhang, J.; Huang, F.; Yan, H. Nonfullerene Acceptor Molecules for Bulk Heterojunction Organic Solar Cells. Chem. Rev. 2018, 118, 3447-3507. [CrossRef]

11. Lu, L.; Zheng, T.; Wu, Q.; Schneider, A.M.; Zhao, D.; Yu, L. Recent Advances in Bulk Heterojunction Polymer Solar Cells. Chem. Rev. 2015, 115, 12666-12731. [CrossRef] [PubMed]

12. Li, H.; Xiao, H.; Ding, L.; Wang, J. Thermostable single-junction organic solar cells with a power conversion efficiency of $14.62 \%$. Sci. Bull. 2018, 63, 340-342. [CrossRef]

13. Meng, L.; Zhang, Y.; Wan, X.; Li, C.; Zhang, X.; Wang, Y.; Ke, X.; Xiao, Z.; Ding, L.; Xia, R.; et al. Organic and solution-processed tandem solar cells with $17.3 \%$ efficiency. Science 2018, 361, 1094-1098. [CrossRef] [PubMed]

14. Grimsdale, A.C.; Chan, K.L.; Martin, R.E.; Jokisz, P.G.; Holmes, A.B. Synthesis of Light-Emitting Conjugated Polymers for Applications in Electroluminescent Devices. Chem. Rev. 2009, 109, 897-1091. [CrossRef] [PubMed]

15. Root, S.E.; Savagatrup, S.; Printz, A.D.; Rodriquez, D.; Lipomi, D.J. Mechanical Properties of Organic Semiconductors for Stretchable, Highly Flexible, and Mechanically Robust Electronics. Chem. Rev. 2017, 117, 6467-6499. [CrossRef]

16. Lin, Y.; Zhan, X. Oligomer Molecules for Efficient Organic Photovoltaics. Acc. Chem. Res. 2016, 49, 175-183. [CrossRef] [PubMed] 
17. Coughlin, J.E.; Henson, Z.B.; Welch, G.C.; Bazan, G.C. Design and Synthesis of Molecular Donors for Solution-Processed High-Efficiency Organic Solar Cells. Acc. Chem. Res. 2014, 47, 257-270. [CrossRef] [PubMed]

18. Lin, Y.; Li, Y.; Zhan, X. Small molecule semiconductors for high-efficiency organic photovoltaics. Chem. Soc. Rev. 2012, 41, 4245-4272. [CrossRef]

19. Sheldon, R.A. The E Factor: Fifteen years on. Green Chem. 2007, 9, 1273-1283. [CrossRef]

20. Po, R.; Bianchi, G.; Carbonera, C.; Pellegrino, A. "All That Glisters Is Not Gold”: An Analysis of the Synthetic Complexity of Efficient Polymer Donors for Polymer Solar Cells. Macromolecules 2015, 48, 453-461. [CrossRef]

21. Po, R.; Bernardi, A.; Calabrese, A.; Carbonera, C.; Corso, G.; Pellegrino, A. From lab to fab: how must the polymer solar cell materials design change?-An industrial perspective. Energy Environ. Sci. 2014, 7, 925-943. [CrossRef]

22. Nitti, A.; Po, R.; Bianchi, G.; Pasini, D. Direct Arylation Strategies in the Synthesis of $\pi$-Extended Monomers for Organic Polymeric Solar Cells. Molecules 2017, 22, 21. [CrossRef] [PubMed]

23. Gobalasingham, N.S.; Thompson, B.C. Direct arylation polymerization: A guide to optimal conditions for effective conjugated polymers. Progr. Polym. Sci. 2018, 83, 135-201. [CrossRef]

24. Matsidik, R.; Komber, H.; Luzio, A.; Caironi, M.; Sommer, M. Defect-free naphthalene diimide bithiophene copolymers with controlled molar mass and high performance via direct arylation polycon-densation. J. Am. Chem. Soc. 2015, 137, 6705-6711. [CrossRef] [PubMed]

25. Bura, T.; Morin, P.-O.; Leclerc, M. En route to defect-free polythiophene derivatives by direct heteroarylation polymerization. Macromolecules 2015, 48, 5614-5620. [CrossRef]

26. Okamoto, J.; Zhang, J.; Housekeeper, J.B.; Marder, S.R.; Luscombe, C.K. C-H arylation reaction: atom efficient and greener syntheses of $\pi$-conjugated small molecules and macromolecules for organic electronic materials. Macromolecules 2013, 46, 8059-8078. [CrossRef]

27. Nitti, A.; Debattista, F.; Abbondanza, L.; Bianchi, G.; Po, R.; Pasini, D. Donor-acceptor conjugated copolymers incorporating tetrafluorobenzene as the $\pi$-electron deficient unit'. J. Polym. Sci. Polym. Chem. 2017, 55, 1601-1610. [CrossRef]

28. Yu, J.; Yan, H.; Zhu, C. Synthesis of Multiply Substituted Polycyclic Aromatic Hydrocarbons by Iridium-Catalyzed Annulation of Ring-Fused Benzocyclobutenol with Alkyne through C-C Bond Cleavage. Angew. Chem. Int. Ed. 2016, 55, 1143-1146. [CrossRef]

29. Koga, Y.; Kaneda, T.; Saito, Y.; Murakami, K.; Itami, K. Synthesis of partially and fully fused polyaromatics by annulative chlorophenylene dimerization. Science 2018, 359, 435-439. [CrossRef]

30. VanVeller, B.; Robinson, D.; Swager, T.M. Triptycene Diols: A Strategy for Planar $\pi$-Systems Demonstrated by the Catalytic Conversion of a PPE into a PPV. Angew. Chem. Int. Ed. 2012, 51, 1182-1186. [CrossRef]

31. Nitti, A.; Bianchi, G.; Po, R.; Swager, T.M.; Pasini, D. Domino Direct Arylation and Cross-Aldol for Rapid Construction of Extended Polycyclic $\pi$-Scaffolds. J. Am. Chem. Soc. 2017, 139, 8788-8791. [CrossRef] [PubMed]

32. Nitti, A.; Signorile, M.; Boiocchi, M.; Bianchi, G.; Po, R.; Pasini, D. Conjugated Thiophene-Fused Isatin Dyes through Intramolecular Direct Arylation. J. Org. Chem. 2016, 81, 11035-11042. [CrossRef] [PubMed]

33. Nitti, A.; Osw, P.; Calcagno, G.; Botta, C.; Etkind, S.E.; Bianchi, G.; Po, R.; Swager, T.M.; Pasini, D. Regiodirected Annulations through One-Pot Direct Arylation-Cross Aldol Condensation for the Rapid Synthesis of $\pi$-Extended Oligomers. Submitted.

34. Nitti, A.; Osw, P.; Abdullah, M.N.; Galbiati, A.; Pasini, D. Scalable Synthesis of Naphthothiophene-based D- $\pi$-D Extended Oligomers through Cascade Direct Arylation Processes. Synlett 2018, 29, 2577-2581.

35. Yao, S.; Kim, B.; Yue, X.; Colon Gomez, M.Y.; Bondar, M.V.; Belfield, K.D. Synthesis of Near-Infrared Fluorescent Two-Photon-Absorbing Fluorenyl Benzothiadiazole and Benzoselenadiazole Derivatives. ACS Omega 2016, 1, 1149-1156. [CrossRef]

36. Ellinger, S.; Graham, K.R.; Shi, P.; Farley, R.T.; Steckler, T.T.; Brookins, R.N.; Taranekar, P.; Mei, J.; Padilha, L.A.; Ensley, T.R.; et al. Donor-Acceptor-Donor-based $\pi$-Conjugated Oligomers for Nonlinear Optics and Near-IR Emission. Chem. Mater. 2011, 23, 3805-3817. [CrossRef]

37. Jung, J.W.; Liu, F.; Russell, T.P.; Jo, W.H. Fluorination on BT consistent: Medium Bandgap Conjugated Polymer for High Per-formance Polymer Solar Cells Exceeding 9\% Power Conversion Efficiency. Adv. Mater. 2015, 27, 7462-7468. [CrossRef] 
38. Pommerehne, J.; Vestweber, H.; Guss, W.; Mahrt, R.F.; Bässler, H.; Porsch, M.; Daub, J. Efficient two layer leds on a polymer blend basis. Adv. Mater. 1995, 7, 551-554. [CrossRef]

39. He, Y.; Li, Y. Fullerene derivative acceptors for high performance polymer solar cells. Phys. Chem. Chem. Phys. 2011, 13, 1970-1983. [CrossRef]

40. Brabec, C.J.; Winder, C.; Sariciftci, N.S.; Hummelen, J.C.; Dhanabalan, A.; van Hal, P.A.; Janssen, R.A.J. A low-bandgap semiconducting polymer for photovoltaic devices and infrared emitting diodes. Adv. Funct. Mater. 2002, 12, 709-712. [CrossRef]

41. Thompson, B.C.; Fréchet, J.M.J. Polymer-Fullerene Composite Solar Cells. Angew. Chem. Int. Ed. 2008, 47, 58-77. [CrossRef] [PubMed]

42. Scharber, M.C.; Mühlbacher, D.; Koppe, M.; Denk, P.; Waldauf, C.; Heeger, A.J.; Brabec, C.J. Design Rules for Donors in Bulk-Heterojunction Solar Cells-Towards 10 \% Energy-Conversion Efficiency. Adv. Mater. 2006, 18, 789-794. [CrossRef]

43. Xin, Y.; Zeng, G.; Zhang, J.; Zhao, X.; Yang, X. A new copolymer based on a D- $\pi$-A or D-A- $\pi$ repeat unit for polymer solar cells employing non-halogenated solvents. J. Mater. Chem. A 2018, 6, 9561-9568. [CrossRef]

44. Liu, Z.; Gao, Y.; Dong, J.; Yang, M.; Liu, M.; Zhang, Y.; Wen, J.; Ma, H.; Gao, X.; Chen, W.; et al. Chlorinated Wide-Bandgap Donor Polymer Enabling Annealing Free Nonfullerene Solar Cells with the Efficiency of 11.5\%. J. Phys. Chem. Lett. 2018, 9, 6955-6962. [CrossRef]

45. Fox, D.; Metrangolo, P.; Pasini, D.; Pilati, T.; Resnati, G.; Terraneo, G. Site-selective supramolecular synthesis of halogen-bonded cocrystals incorporating the photoactive azo group. CrystEngComm 2008, 10, 1132-1136. [CrossRef]

46. Agnes, M.; Nitti, A.; Vander Griend, D.A.; Dondi, D.; Merli, D.; Pasini, D. A chiroptical molecular sensor for ferrocene. Chem. Commun. 2016, 52, 11492-11495. [CrossRef]

47. Hu, L.; Qiao, W.; Gu, W.; Zhu, X.; Wang, C.; Wang, Z.Y. Broadband polymer photodetectors with a good trade-off between broad response and high detectivity by using combined electron-deficient moieties. J. Mater. Chem. C 2020. [CrossRef]

48. Liu, Z.; Wu, Y.; Zhang, Q.; Gao, X. Non-fullerene small molecule acceptors based on perylene diimides. J. Mater. Chem. A 2016, 4, 17604-17622. [CrossRef] 